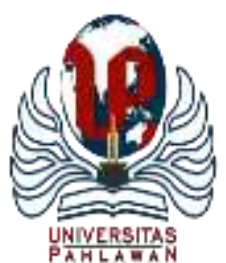

\title{
JURNALBASICEDU
}

Volume 5 Nomor 6 Tahun 2021 Halaman 6185 - 6195

Research \& Learningin Elementary Education https://jbasic.org/index.php/basicedu

\section{Pengembangan Media Komik Bermuatan IPA Berbasis Model Inkuiri Terbimbing dalam Meningkatkan Motivasi Siswa Sekolah Dasar}

\author{
Nursina Sari ${ }^{1 凶}$, Tursina Ratu ${ }^{2}$ \\ Pendidikan Guru Sekolah Dasar, Universitas Muhammadiyah Mataram, Indonesia ${ }^{1}$ \\ Pendidikan Fisika, Universitas Samawa, Indonesia ${ }^{2}$ \\ E-mail: Sarinursina1234@gmail.com ${ }^{1}$, ratutursina@gmail.com ${ }^{2}$
}

\begin{abstract}
Abstrak
Konsep pembelajaran bermuatan IPA masih dianggap kurang menarik bagi siswa kelas 5 di SDN 4 Kuranji, hal ini terukur dari kegiatan pembelajaran yang menunjukkan motivasi belajar yang rendah. Oleh karena itu penelitian ini bertujuan untuk mengetahui: (1) kelayakan (2) kepraktisan, dan (3) keefektifan dari media komik bermuatan IPA berbasis model inkuiri terbimbing dalam meningkatkan motivasi siswa Sekolah Dasar (SD). Penelitian ini adalah penelitian dan pengembangan yang mengadaptasi model dari Borg \& Gall. Pada pelaksanaan uji lapangan operasional, sampel ditentukan dengan teknik one group pre tes- post test design, yang menggunakan instrumen lembar angket dan observasi. Hasil penelitian yang diperoleh (1) Media komik bermuatan IPA layak digunakan dengan data persentasi validator ahli materi sebesar 93,3\%; validator ahli media sebesar 97,8\%; validator teman sejawat sebesar 97,3\%, dengan kriteria "sangat valid"(2) Media komik bermuatan IPA praktis digunakan dengan data persentasi sebesar 96\%, dengan kriteria "sangat praktis" (3) Media komik bermuatan IPA efektif secara signifikan dalam meningkatkan motivasi dengan hasil skor gain motivasi siswa sebesar 1 dengan kriteria "Gain tinggi".
\end{abstract}

Kata Kunci: Komik, Model Inkuiri Terbimbing, Motivasi.

\begin{abstract}
The concept of science learning is considered less attractive for grade 5 students at SDN4 Kuranji, these things are from learning activities which show that learning is still low. Therefore, this study aims to determine: (1) practicality (2) practicality, and (3) the effectiveness of comics media containing science based on guided inquiry models in increasing the motivation of elementary school students (SD). This research is research and development that adapts the model from Borg \& Gall. In the implementation of the operational field test, the sample was determined using the one group pre test-post test design technique, which used a questionnaire and observation sheet as an instrument. The research results obtained (1) Science content comic media is suitable for use with material expert validator percentage data of 93.3\%; media expert validators by $97.8 \%$; peer validator is $97.3 \%$, with the criterion of "very valid" (2) Comic media containing science is practically used with a percentage data of 96\%, with the criterion of "very practical" (3) Comic media containing science is significantly effective in increasing motivation with the result of a motivational gain score of 1 with the criteria of "High gain".
\end{abstract}

Keywords: Comics, Guided Inquiry Model, Motivation

Copyright (c) 2021 Nursina Sari, Tursina Ratu

$\triangle$ Corresponding author :

Email : Sarinursina1234@gmail.com

DOI : https://doi.org/10.31004/basicedu.v5i6.1793

ISSN 2580-3735 (Media Cetak)

ISSN 2580-1147 (Media Online) 
6186 Pengembangan Media Komik Bermuatan IPA Berbasis Model Inkuiri Terbimbing dalam Meningkatkan Motivasi Siswa Sekolah Dasar - Nursina Sari, Tursina Ratu

DOI: https://doi.org/10.31004/basicedu.v5i6.1793

\section{PENDAHULUAN}

Kurikulum adalah suatu komponen panduan yang bersifat dinamis dalam melaksanakan pendidikan. Untuk itu segala rangkaian komponen yang tertuang dalam kurikulum tidak lain merupakan upaya perwujudan dalam pencapaian tujuan pendidikan yaitu mencerdaskan kehidupan bangsa seperti yang tertuang dalam UUD 1945. Lahirnya kurikulum 2013 sebagai upaya penyempurnaan kurikulum sebelumnya adalah salah satu langkah upaya pemerintah untuk meningkatkan kualitas pendidikan dengan cara mengatur jalannya pelaksanaan pembelajaran secara tematik-integrative yaitu pendekatan pembelajaran dalam sistem pendidikan yang mengitegrasikan berbagai kompetensi dasar dari berbagai muatan konsep pelajaran ke dalam suatu tema tertentu yang tentunya berorientasi pada pengembangan pengetahuan, sikap, dan keterampilan agar dapat mengembangkan potensi setiap anak sehingga cerdas secara intelektual, emosional dan spritualnya (Hidayah et al., 2015; Hakim, 1970). Demi mewujudkannya dibutuhkan beberapa aspek dasar salah satunya adalah muatan konsep Ilmu Pengetahuan Alam (IPA).

IPA dalam pembelajaran di jenjang Sekolah Dasar (SD) merupakan salah satu muatan konsep yang wajib dipelajari oleh siswa di usia dini, dikarenakan memuat konsep ilmu tentang gejala alam, makhluk hidup dan lain sebagainya yang berkaitan dengan kehdupan sehari-hari. Menurut James conant (Desstya, 2015) bahwa IPA merupakan sederatan konsep dan skema konseptual yang saling berhubungan antara satu dengan yang lainnya sebagai hasil eksperimentasi dan observasi, IPA telah diklasifikasikan menjadi tiga ranah yaitu IPA sebagai produk, IPA sebagai proses, dan IPA sebagai sikap (Silviana et al., 2018). Dengan begitu muatan IPA hendaknya mengarahkan siswa agar dapat memiliki pengetahuan, keterampilan dasar dan minat serta penghargaannya terhadap tempat mereka berpijak (Awang, 2015). Jadi guru hendaknya menyampaikan pembelajaran sesuai karakteristik pembelajaran di atas.

Proses pembelajaran dalam keberhasilannya dipengaruhi oleh beberapa faktor meliputi faktor internal dan faktor eksternal. Dimana faktor internal salah satunya berupa motivasi dari siswa. Mc. Donald (Sidik \& Sobandi, 2018; Emda, 2018) menyatakan bahwa motivasi merupakan suatu tanggapan yang hadir terhadap suatu tujuan tertentu yang diikuti oleh suatu perubahan atau dorongan energi yang berada dalam diri seseorang yang ditandai dengan hadirnya suatu perasaan dan afeksi yang dapat disadari atau tidak. Dengan begitu dalam melakukan sesuatu tindakan sehingga ciri-ciri motivasi pada siswa dapat terukur dari hal-hal: a) Tekun menghadapi tugas yang diberikan, b) Ulet menghadapi kesulitan yang ada, c) Menunjukkan minat terhadap bermacam-macam persoalan "untuk orang dewasa", d) Lebih senang bekerja secara mandiri, e) Cepat bosan pada penugasan yang rutin, f) Dapat mempertahankan pendapatnya, g) Tidak mudah goyah untuk hal yang diyakini, h) Senang mencari dan memecahkan persoalan yang ada (Rumhadi, 2017). Jadi dengan adanya motivasi siswa dapat mengembangkan inisiatif dan aktivitasnya agar dapat mengarahkan sikap tekun untuk melakukan suatu kegiatan belajar. Sikap sebagai salah satu kemampuan yang dimiliki seorang siswa terhadap ilmu pengetahuan juga merupakan indikator penting dari bagaimana cara mereka menempatkan diri dalam melakukan proses pembelajaran.

Berdasarkan hasil observasi dan wawancara yang dilakukan di SDN 4 Kuranji kelas 5, ditemukan permasalahan bahwa motivasi siswa dalam pembelajaran konsep bermuatan IPA masih rendah, hal ini terukur dari perhatian siswa selama pembelajaran berlangsung terlihat tidak antusias. Kebanyakan siswa kurang memperhatikan guru karena ada yang sibuk bercanda dengan teman-temannya, ada yang hanya duduk sibuk menggambar. Selain itu, hal yang yang teramati juga disaat siswa diberi penugasan secara mandiri, hanya beberapa siswa yang terlihat serius mengerjakan selebihnya ada yang sibuk menggambar, ada juga beberapa siswa yang sibuk mencari contekan pada tugas yang dikerjakan temannya. Permasalahan tersebut bisa jadi disebabkan oleh minimnya penggunaan media oleh guru. Dimana pembelajaran yang dilaksanakan sekedar memanfaatkan buku paket siswa dan guru sekedar menjelaskan konsep dengan metode ceramah, memanfaatkan benda-benda yang ada disekitar dan diselingi dengan kegiatan tanya jawab serta penugasan 
6187 Pengembangan Media Komik Bermuatan IPA Berbasis Model Inkuiri Terbimbing dalam Meningkatkan Motivasi Siswa Sekolah Dasar - Nursina Sari, Tursina Ratu

DOI: https://doi.org/10.31004/basicedu.v5i6.1793

tanpa adanya penggunaan bentuk media lainnya, menyebabkan kurang menariknya pembelajaran bermuatan IPA. Meskipun terdapat alat peraga KIT akan tetapi kelengkapannya tidak seperti dulu. Hal ini tentunya menjadi masalah bagi guru untuk mengembangkan kreativitasnya dikarenakan keterbatasan wawasan mengenai jenis-jenis media, keterbatasan biaya dan juga waktu. Permasalahan tersebut tentunya berdampak pada motivasi belajar siswa yang akhirnya mempengaruhi hasil belajar siswa.

Alternatif pilihan yang dapat dipilih sebagai solusi untuk meningkatkan motivasi belajar siswa di kelas yaitu melakukan pengembangan produk media pembelajaran. Dimana media menurut kurnia ((Kamaladini et al., 2021); (Zaenal Fais et al., 2019);(Wibowo \& Koeswanti, 2021)) yaitu suatu alat penyampaian pesan kepada siswa yang bertujuan agar dapat merangsang minat, perhatian atau ketertarikan maupun pikiriannya guna mengefektifkan komunikasi antara guru dan siswa dalam mengikuti suatu pembelajaran, sehingga memberikan pengaruh secara psikologis terhadap siswa. Belajar menurut Arsyad (Anggraeni et al., 2021) merupakan suatu proses interaksi seseorang dengan lingkungan yang menyebabkan perubahan tingkat pengetahuan, kemampuan, maupun sikap. Hal ini sejalan dengan pernyataan Tella (Sari \& Prodjosantoso, 2018) bahwa proses pembelajaran yang hanya menggunakan buku sebagai satu-satunya sumber belajar tanpa diberikannya suatu media akan menjadikan suasana pembelajaran menjadi kurang menarik dan membosankan yang mengakibatkan kemampuan dan kreativitas anak tidak berkembang, sehingga mempengaruhi minat dan motivasi belajarnya. Untuk itu, unsur pemanfaatan suatu media penting dalam proses pembelajaran.

Komik sebagai salah satu dari bentuk media yang dapat dipilih sebagai alternatif dalam meningkatkan belajar siswa, dimana komik merupakan media jenis visual yang memiliki kekuatan untuk menyampaikan suatu informasi secara popular, dan lebih mudah untuk dimengerti karena terdiri atas gambar dan tulisan yang dirangkai dalam suatu alur cerita yang menarik dan mudah untuk di baca dan dipahami, sehingga dapat membantu mengembangkan imajinasi, dan kepribadian anak serta memberikan pengalaman belajar yang menyenangkan dan akhirnya berdampak pada peningkatan hasil belajarnya ((Widyawati \& Prodjosantoso, 2015);(Siska \& Kristiawan, 2021)). Dalam hal ini, pengembangan media komik oleh peneliti menyajikan konsep materi bermuatan IPA yang cocok untuk membantu siswa dalam memahami hal yang bersifat abstrak. Terlebih salah satu konsep materi muatan IPA yang dipelajari adalah mengenai kalor. Sub materi kalor khususnya konsep perpindahan kalor sangat erat dengan kehidupan sehari-hari, dengan begitu indikator pencapainnya kompetensinya sesuai dengan pembelajaran yang berbasis penemuan yaitu mengenai peran kalor dalam merubah wujud benda.

Berkaitan dengan ini, pendekatan ilmiah yang dapat digunakan adalah model inkuiri. Dimana model pembelajaran inkuiri (Setiasih \& Panjaitan, 2016) merupakan model pembelajaran yang menekankan pada pengembangan mental (intelektual), dengan rangkaian pembelajaran yang menekankan pada proses berpikir secara sistematis, kritis dan analitis untuk mencari maupun menemukan sendiri jawaban dari suatu masalah yang dipertanyakan untuk dipecahkan baik dalam proses pembelajaran maupun dari suatu lingkungan dimana siswa berada. Model pembelajaran inkuiri menurut Sound dan Trowbridge (Lahadisi, 2014) terdiri atas beberapa jenis yang dapat dipilih sesuai dengan perkembangan anak meliputi Pembelajaran inkuiri terbimbing (Guided Inquiry), Pembelajaran inkuiri termodifikasi (Modified Inquiry) ,dan Pembelajaran inkuiri bebas (Free inquiry). Model inkuiri terbimbing sebagai suatu proses berpikir yang ditempuh oleh siswa yang diawali dengan proses pengajuan pertanyaan yang kemudian menerapkan pengetahuan yang ada melalui kegiatan eksperimen (Sari \& A.K. Prodjosantoso, 2016). Dengan begitu sangat sesuai untuk dikembangkan dengan alur cerita media komik sebagai penghubung antara konsep materi satu dengan yang lainnya dalam pembelajaran konsep bermuatan IPA untuk siswa SD.

Dari uraian permasalahan di atas, peneliti ingin mengembangkan produk media pembelajaran komik bermuatan IPA berbasil model inkuiri terbimbing untuk meningkatkan motivasi belajar siswa sekolah dasar. Media pembelajaran berbentuk komik memiliki banyak kelebihan dimana cerita yang disusun dengan alur 
6188 Pengembangan Media Komik Bermuatan IPA Berbasis Model Inkuiri Terbimbing dalam Meningkatkan Motivasi Siswa Sekolah Dasar - Nursina Sari, Tursina Ratu

DOI: https://doi.org/10.31004/basicedu.v5i6.1793

yang menarik dan dekat dengan kehidupan sehari-hari sehingga menarik minat membaca siswa dan lebih cepat memahami konsep pembelajaran yang disampaikan oleh guru.

\section{METODE PENELITIAN}

Penelitian ini berjenis Research and Development (R\&D), menurut Sugiyono (Kamaladini et al., 2021) merupakan suatu metode atau proses yang dalam penelitian sering digunakan untuk memvalidasi, mengembangkan suatu produk atau menyempurnakan suatu produk yang sudah ada, maupun yang dapat dipertanggung jawabkan. Adapun desain kelas yang digunakan adalah one group pretes- posttest design dan mengadaptasi tahapan dari model Barg and gall, yang ditunjukkan oleh Gambar berikut:

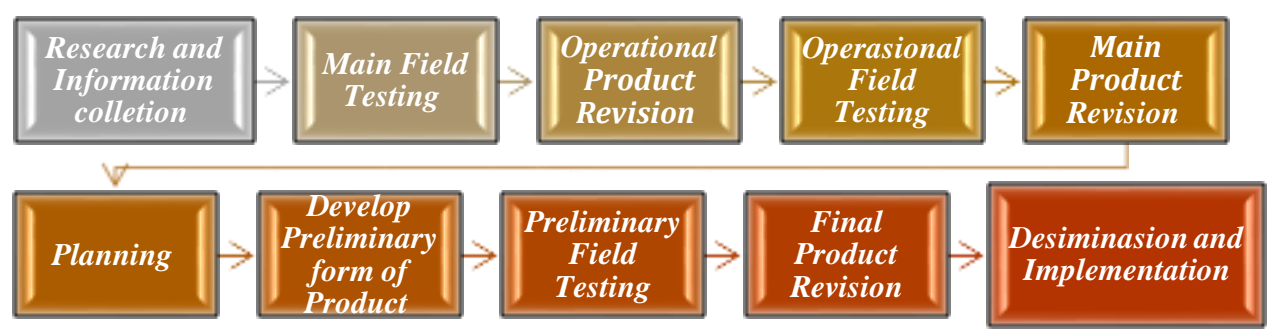

\section{Gambar Desain Model Pengembangan yang Diadaptasi Dari Barg and gall}

Adapun jenis data dalam penelitian ini yaitu kualitatif dan kuantitatif. Dimana jenis data kualitatif diperoleh dari hasil wawancara, observasi, komentar, kritik, dan saran yang diperoleh melalui lembar angket, sedangkan jenis data kuantitatif diperoleh dari skor lembar angket validasi produk, respon siswa, dan lembar observasi keterlaksanaan proses pembelajaran. Subjek uji coba lapangan yang berjumlah 6 orang siswa yang diambil pada kelas 6 sementara subjek uji Coba Operasional berjumlah 12 orang siswa kelas 5 SDN 4 Kuranji. Adapun analisis data hasil validasi ahli modul dan ahli materi serta rekan sejawat yang dilakukan dengan mencari skor rata-rata penilaian dari validator maupun rekan sejawat dengan rumus yang berikut (Kamaladini et al., 2021) :

$$
\text { Nilai Akhir }=\frac{\text { Skor yang diperoleh }}{\text { Skor Maksimum }} \times 100
$$

Suatu media dapat disimpulkan layak atau valid untuk digunakan jika memiliki kriteria "Baik", Adapun konversi skor dapat mengacu pada kriteria skor penialaian pada Tabel 1. Berikut (Kamaladini et al., 2021):

Tabel 1. Kategori Kelayakan Produk

\begin{tabular}{cll}
\hline $\begin{array}{c}\text { Interval } \\
\text { Skor }\end{array}$ & $\begin{array}{c}\text { Kriteria } \\
\text { Kelayakan }\end{array}$ & Keterangan \\
\hline $0<\mathrm{NV} \leq 55$ & Tidak Valid & Tidak sesuai \\
\hline $55<\mathrm{NV} \leq 75$ & Cukup valid & kurang sesuai \\
\hline $75<\mathrm{NV} \leq 85$ & Valid & cukup sesuai \\
\hline $85<\mathrm{NV} \leq 100$ & Sangat Valid & Sesuai \\
\hline
\end{tabular}

Sementara untuk kepraktisan dari produk media yang kembangkan, setelah diperoleh suatu nilai, kemudian akan dikonversi dengan mengacu pada kriteria skor penilaian pada Tabel 2 berikut (Hariani et al., 2021): 

Meningkatkan Motivasi Siswa Sekolah Dasar - Nursina Sari, Tursina Ratu

DOI: https://doi.org/10.31004/basicedu.v5i6.1793

Tabel 2. Kategori Kepraktisan Produk

\begin{tabular}{cll}
\hline $\begin{array}{c}\text { Tingkat } \\
\text { Pencapaian }\end{array}$ & \multicolumn{1}{c}{ Kategori } & \multicolumn{1}{c}{ Keterangan } \\
\hline $86 \%-100 \%$ & Sangat Praktis & Dapat digunakan tanpa revisi \\
\hline $70 \%-85 \%$ & Cukup Praktis & Dapat digunakan dengan revisi ringan \\
\hline $60 \%-69 \%$ & Tidak Praktis & Tidak dapat digunakan \\
\hline $00 \%-59 \%$ & Sangat Tidak Praktis & Tidak dapat digunakan \\
\hline
\end{tabular}

Data variabel motivasi yang diukur melalui lembar angket respon siswa, untuk peningkatannya dapat diukur menggunakan persamaan nilai Gain yang dikemukakan oleh Bao (Sari \& Prodjosantoso, 2018) sebagai berikut:

$$
\text { Gain standar }=\frac{\text { skor sesudah }- \text { skor sebelum }}{\text { skor maksimum }- \text { skor sebelum }}
$$

Kemudian nilai gain yang diperoleh dikonversikan dengan kriteria Gain dari Knight (Sari \& Rahman, 2018) pada Tabel 3 berikut:

Tabel 3.Kriteria Gain Skor

\begin{tabular}{ll}
\hline Interval Skor & Kriteria Gain \\
\hline $\mathrm{g} \geq 0,7$ & $\mathrm{~g}$-Tinggi \\
\hline $0,7>\mathrm{g} \geq 0,3$ & $\mathrm{~g}$-Sedang \\
\hline $\mathrm{g}<0,3$ & $\mathrm{~g}$-Rendah \\
\hline
\end{tabular}

\section{HASIL DAN PEMBAHASAN}

Penelitian pengembangan ini menghasilkan produk berupa media komik berbasis model inkuiri terbimbing, dimana tahapan-tahapan yang dilakukan dalam penelitian ini mengadaptasi dari model Barg \& Gall. Tahapan awal yang dilakukan adalah studi lapangan merupakan kegiatan penelitian dan pengumpulan data dengan teknik pengamatan (observasi) dan wawancara pada guru yang bertujuann untuk memperoleh informasi mengenai pelaksanaan pembelajaran IPA yang ada di sekolah yang dilakukan di SDN 4 Kuranji, dimana permasalahan yang ditemukan bahwa motivasi belajar siswa masih rendah. Hal ini terukur pada proses pembelajaran yang sedang berlangsung, terlihat para siswa kurang antusias, terdapat beberapa siswa yang suka mengantuk sehingga tidak fokus memperhatikan guru, bahkan ada yang sibuk bercanda dengan temantemannya, dan ada yang sibuk menggambar. Selain itu, hal yang yang teramati juga disaat siswa diberi penugasan secara mandiri, hanya beberapa siswa yang terlihat serius mengerjakan selebihnya ada yang sibuk menggambar, ada juga beberapa siswa yang sibuk mencari contekan pada tugas yang dikerjakan temannya.

Pada tahap kedua peneliti melakukan kegiatan perencanaan berupa analisis struktur isi maupun konsep dan perumusan tujuan pembelajaran. Berdasarkan hasil analisis kebutuhan yang ada di lapangan, berdasarkan analisis peneliti akan mengembangkan produk berupa media komik berbasis model inkuiri terbimbing bermuatan IPA sebagai solusi untuk meningkatkan permasalahan mengenai rendahnya motivasi belajar siswa dalam proses pembelajaran. Kemudian tahap selanjutnya adalah tahap ketiga dan keempat yaitu tahap pengembangan draft produk media komik yang dilanjutkan dengan tahap validasi oleh validator maupun teman sejawat. yang bertujuan untuk menilai kelayakannya. Adapun hasil data kelayakan produk yang diperoleh berdasarkan penilaian validator ahli materi yang disajikan pada Tabel 4 di bawah ini: 
6190 Pengembangan Media Komik Bermuatan IPA Berbasis Model Inkuiri Terbimbing dalam Meningkatkan Motivasi Siswa Sekolah Dasar - Nursina Sari, Tursina Ratu

DOI: https://doi.org/10.31004/basicedu.v5i6.1793

Tabel 4. Rekapitulasi Hasil Validasi Ahli Materi

\begin{tabular}{clcc}
\hline \multirow{2}{*}{ No } & \multicolumn{1}{c}{ Aspek } & $\begin{array}{c}\text { Ahli } \\
\text { Materi }\end{array}$ & Skor \\
\hline 1 & Relevansi materi dengan kurikulum 2013 & 5 & 5 \\
\hline 2 & Kedalaman konsep materi & 4 & 4 \\
\hline 3 & $\begin{array}{l}\text { Materi dapat meningkatkan kompetensi sains } \\
\text { siswa }\end{array}$ & 4 & 4 \\
\hline 4 & Kesesuaian media terhadap materi & 5 & 5 \\
\hline 5 & Penyajian materi menarik minat siswa & 5 & 5 \\
\hline 6 & $\begin{array}{l}\text { Pembelajaran menggunakan media komik } \\
\text { meningkatkan motivasi siswa }\end{array}$ & 5 & 5 \\
\hline \multicolumn{2}{c}{ Jumlah Skor Total } & $\mathbf{2 8}$ & $\mathbf{2 8}$ \\
\hline$\quad$ Hasil uji validasi & \multicolumn{2}{c}{ Sangat valid } \\
\hline
\end{tabular}

Adapun data hasil validasi ahli media dari produk media komik berbasis model inkuiri terbimbing yang tersaji pada Tabel 5 berikut:

Tabel 5. Rekapitulasi Hasil Validasi Ahli Media

\begin{tabular}{clcc}
\hline \multirow{2}{*}{ No } & \multicolumn{1}{c}{ Aspek } & $\begin{array}{c}\text { Ahli } \\
\text { Media }\end{array}$ & Skor \\
\hline 1 & Tampilan fisik komik & 5 & 5 \\
\hline 2 & Sistematika anatomi komik & 5 & 5 \\
\hline 3 & Mutu gambar komik & 5 & 5 \\
\hline 4 & Alur cerita menarik motivasi siswa & 5 & 5 \\
\hline 5 & Sistematika penulisan sesuai EYD & 5 & 5 \\
\hline 6 & Kesesuaian jenis balon yang digunakan & 4 & 4 \\
\hline 7 & Ketepatan bahasa yang digunakan & 5 & 5 \\
\hline 8 & Kemenarikan kombinasi warna yang digunakan & 5 & 5 \\
\hline 9 & Keawetan bahan yang digunakan & $\mathbf{4 4}$ & $\mathbf{4 4}$ \\
\hline \multicolumn{2}{c}{ Skor Total } & $\mathbf{9 7 , 8}$ \\
\hline \multicolumn{2}{c}{ Sangat valid }
\end{tabular}

Sementara data hasil validasi rekan sejawat dari produk media komik berbasis model inkuiri terbimbing yang tersaji pada Tabel 6 berikut:

Tabel 6. Rekapitulasi Hasil Validasi Teman Sejawat

\begin{tabular}{llcc}
\hline \multirow{2}{*}{ No } & \multirow{2}{*}{ Aspek } & \multicolumn{2}{c}{ Teman Sejawat } \\
\cline { 3 - 4 } & & $\mathbf{1}$ & $\mathbf{2}$ \\
\hline 1 & Relevansi konsep materi dengan kurikulum 2013 & 5 & 5 \\
\hline 2 & Kedalaman konsep materi & 5 & 5 \\
\hline
\end{tabular}


6191 Pengembangan Media Komik Bermuatan IPA Berbasis Model Inkuiri Terbimbing dalam Meningkatkan Motivasi Siswa Sekolah Dasar - Nursina Sari, Tursina Ratu

DOI: https://doi.org/10.31004/basicedu.v5i6.1793

\begin{tabular}{clccc}
\hline \multirow{2}{*}{ No } & & \multicolumn{2}{c}{ Aspek } & \multicolumn{2}{c}{ Teman Sejawat } \\
\cline { 3 - 4 } & & $\mathbf{1}$ & $\mathbf{2}$ \\
\hline 3 & Materi dapat meningkatkan kompetensi sains siswa & 5 & 4 \\
\hline 4 & Kesesuaian media terhadap materi & 5 & 5 \\
\hline 5 & Penyajian materi menarik minat siswa & 5 & 5 \\
\hline 6 & $\begin{array}{l}\text { Pembelajaran menggunakan media komik meningkatkan } \\
\text { motivasi siswa }\end{array}$ & 4 & 5 \\
\hline 7 & Tampilan fisik komik & 5 & 5 \\
\hline 8 & Sistematika anatomi komik & 5 & 5 \\
\hline 9 & Mutu gambar komik & 5 & 5 \\
\hline 10 & Alur cerita menarik motivasi siswa & 5 & 4 \\
\hline 11 & Sistematika penulisan sesuai EYD & 5 & 5 \\
\hline 12 & Kesesuaian jenis balon yang digunakan & 5 & 5 \\
\hline 13 & Ketepatan bahasa yang digunakan & 5 & 4 \\
\hline 14 & Kemenarikan kombinasi warna yang digunakan & 5 & 5 \\
\hline 15 & Keawetan bahan yang digunakan & 5 & 5 \\
\hline & Skor Total & $\mathbf{7 4}$ & $\mathbf{7 2}$ \\
\hline & Hasil Uji Validasi & $\mathbf{9 8 , 7}$ & $\mathbf{9 6 , 0}$ \\
\hline \multirow{2}{*}{ Rata-Rata Hasil Validasi } & $\mathbf{9 7 , 3}$ & Sangat Valid \\
\hline & Kriteria & &
\end{tabular}

Berdasarkan data-data di atas yaitu hasil validasi oleh validator media, validator materi, maupun teman sejawat diperoleh hasil bahwa rekapitulasi hasil skor validasi ahli meteri sebesar 93,3\% dalam kategori "Sangat Valid", untuk hasil skor validasi ahli media yang diperoleh sebesar 97,7 \% dalam kategori "Sangat Valid", hasil skor validasi rekan sejawat sebesar 97,3 \% dalam kategori "Sangat Valid". Dengan begitu media komik berbasis model inkuiri terbimbing dapat disimpulkan memenuhi kriteria sangat valid digunakan dalam pembelajaran. Tahap kelima adalah kegiatan revisi, merupakan tahap perbaikan sesuai saran dan masukan dari validator maupun teman sejawat. Dimana terdapat beberapa indikator yang perlu diperbaiki meliputi tampilan fisik dan kemenarikan kombinasi warna yang digunakan, serta mutu gambar pada komik, yang tersaji pada Tabel 7 berikut:

Tabel 7. Rekapitulasi Hasil Revisi dari Validator dan teman Sejawat Produk Media Komik Berbasis Model Inkuiri Terbimbing

Sebelum
MEMBUAT GARAM
reEI!


6192 Pengembangan Media Komik Bermuatan IPA Berbasis Model Inkuiri Terbimbing dalam Meningkatkan Motivasi Siswa Sekolah Dasar - Nursina Sari, Tursina Ratu

DOI: https://doi.org/10.31004/basicedu.v5i6.1793

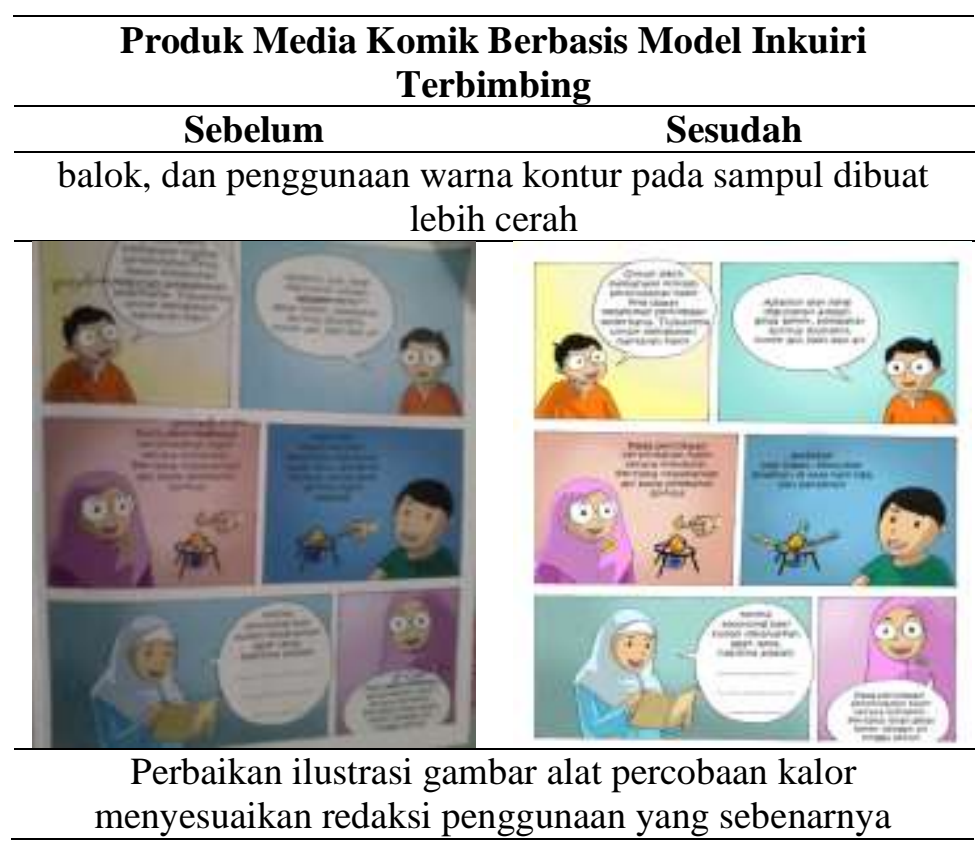

Selanjutnya tahap ke enam kegiatan yang dilakukan setelah revisi adalah uji coba lapangan utama (uji coba terbatas) yang bertujuan untuk mengetahui kepraktisan dari produk media komik yang dilakukan pada siswa kelas 6 dengan jumlah 6 orang di SDN 4 Kuranji untuk melihat kepraktisan dari produk yang dikembangkan. Adapun perolehan data hasil mengenai kepraktisan dari penggunaan media dalam penelitian terangkum pada tabel 8 berikut:

Tabel 8. Rekapitulasi Hasil Respon Siswa

\begin{tabular}{llcl}
\hline \multirow{2}{*}{ NO } & \multirow{2}{*}{ NAMA } & \multicolumn{2}{c}{ Respon Siswa } \\
\cline { 3 - 4 } & & Skor & Keterangan \\
\hline 1. & AIS & $100 \%$ & Sangat Praktis \\
\hline 2. & DO & $94 \%$ & Sangat Praktis \\
\hline 3. & JR & $100 \%$ & Sangat Praktis \\
\hline 4 & ZNH & $92 \%$ & Sangat Praktis \\
\hline 5. & RD & $94 \%$ & Sangat Praktis \\
\hline 6. & RM & $96 \%$ & Sangat praktis \\
\hline \multicolumn{2}{r}{ Jumlah } & $\mathbf{5 7 6 \%}$ & Sangat praktis \\
\hline \multicolumn{2}{c}{ Rata-rata } & $\mathbf{9 6 \%}$ & Sangat praktis \\
\hline
\end{tabular}

Hasil Tabel 8 di atas diperoleh informasi bahwa hasil kepraktisan dari media komik berbasis model inkuiri terbimbing yang diterapkan pada kelas 6 di SDN 5 Kuranji. sebagai uji kepraktisan, didapatkan data persentase sebesar $96 \%$ tergolong pada kategori "Sangat Praktis", sehingga dapat di pahami bahwa media komik berbasis model inkuiri terbimbing telah memenuhi unsur kepraktisan yang dapat digunakan pada siswa kelas 5 di SDN 4 Kuranji. Tahap ketujuh yaitu revisi untuk penyempurnaan produk berdasarkan hasil uji coba kepraktisan. Oleh karena tidak ada revisi pada tahap ini melainkan perbaikan teknis pelaksanaan pembelajaran berupa produk media komik yang diberikan harus masing-masing satu tiap siswa untuk tiap kelompok agar setiap siswa memiliki kesempatan yang sama dalam menggunakan media dan waktu yang diberikan untuk membaca komik lebih diperpanjang yang awalnya hanya 2 menit menjadi 2-5 menit agar lebih siap untuk menggunakan produk media komik dalam proses belajar. 
6193 Pengembangan Media Komik Bermuatan IPA Berbasis Model Inkuiri Terbimbing dalam Meningkatkan Motivasi Siswa Sekolah Dasar - Nursina Sari, Tursina Ratu

DOI: https://doi.org/10.31004/basicedu.v5i6.1793

Pada tahap selanjutnya yaitu tahap kedelapan merupakan uji coba lapangan operasional/empiris ini bertujuan untuk menguji keterlaksanaan dalam pemakaian media komik berbasis model inkuiri terbimbing dan untuk mengetahui hasil peningkatan motivasi belajar siswa kelas 5 SD. Untuk mengukur peningkatan motivasi siswa, peneliti menggunakan lembar angket motivasi yang diberikan kepada 12 orang siswa.Selanjutnya mengenai hasil data peningkatan motivasi belajar siswa yang diperoleh melalui instrumen lembar angket motivasi siswa diperoleh hasil yang terangkum pada Tabel 9 di bawah ini:

Tabel 9. Rekapitulasi Hasil Respon Siswa

\begin{tabular}{llccc}
\hline \multirow{2}{*}{ No } & Nama & \multicolumn{2}{c}{ Skor Motivasi Siswa } & \\
\cline { 3 - 4 } & Siswa & Sebelum & Sesudah & N-Gain \\
\hline 1 & AIM & 58 & 78 & 0,5 \\
\hline 2 & AMD & 60 & 82 & 0,6 \\
\hline 3 & AL & 56 & 85 & 0,7 \\
\hline 4 & AN & 68 & 100 & 1,0 \\
\hline 5 & DYA & 52 & 92 & 0,8 \\
\hline 6 & DFE & 46 & 80 & 0,6 \\
\hline 7 & EKN & 66 & 95 & 0,9 \\
\hline 8 & FF & 64 & 98 & 0,9 \\
\hline 9 & GAF & 54 & 86 & 0,7 \\
\hline 10 & NU & 60 & 76 & 0,4 \\
\hline 11 & PD & 48 & 90 & 0,8 \\
\hline 12 & TR & 50 & 86 & 0,7 \\
\hline \multicolumn{7}{l}{ Rata-rata } & $\mathbf{5 1}$ & $\mathbf{8 7}$ & $\mathbf{1}$ \\
\hline
\end{tabular}

Berdasarkan data Tabel 9 tersebut, dapat diketahui bahwa terjadi peningkatan motivasi belajar pada siswa kelas 5 SDN 4 Kuranji yang ditunjukkan oleh nilai dari skor rata-rata gain standar yaitu sebesar 1 yang menunjukkan bahwa nilai tersebut masuk dalam kriteria "Gain tinggi". Kemudian tahap sembilan adalah tahap revisi produk, pada tahapan ini tidak ada yang perlu direvisi dikarenakan sudah memenuhi unsur layak, praktis, dan efektif. Adapun tahap terakhir adalah diseminasi yang dilakukan secara terbatas yaitu hanya di sekolah tempat penelitian dilakukan.

Dari data hasil penilitian yang dilakukan oleh peneliti di atas, bahwa perolehan nilai Gain standar dapat disimpulkan bahwa motivasi siswa mengalami peningkatan, yang terlihat pada skor sebesar 1 dengan kriteria "Gain tinggi". Hal ini didukung oleh penelitian (Mujahadah et al., 2021) bahwa produk media pembelajaran komik efektif dalam meningkatkan hasil dan minat belajar matematika siswa kelas III SD dengan nilai interpretasi rata-rata hasil belajar sebesar $87,5 \%$ dan minat belajar sebesar 33,56\%. Oleh karena itu, secara teoritis maupun secara praktis dari hasil penelitian di atas bahwa penggunaan produk media komik berbasis model inkuiri terbimbing dapat meningkatkan motivasi belajar siswa kelas 5 SD pada muatan konsep pembelajaran IPA.

\section{KESIMPULAN}

Berdasarkan hasil penelitian yang dilakukan, dapat disimpulkan bahwa (1) Media komik bermuatan IPA layak digunakan dengan data persentasi validator ahli materi sebesar 93,3\%; validator ahli media sebesar 97,8\%; validator teman sejawat sebesar 97,3\%, dengan kriteria "sangat valid", (2) Media komik bermuatan 
6194 Pengembangan Media Komik Bermuatan IPA Berbasis Model Inkuiri Terbimbing dalam Meningkatkan Motivasi Siswa Sekolah Dasar - Nursina Sari, Tursina Ratu

DOI: https://doi.org/10.31004/basicedu.v5i6.1793

IPA praktis digunakan dengan data persentasi sebesar 96\%, dengan kriteria "sangat praktis", (3) Media komik bermuatan IPA efektif secara signifikan dalam meningkatkan motivasi dengan hasil skor gain motivasi siswa sebesar 1 dengan kriteria "Gain tinggi".

\section{UCAPAN TERIMA KASIH}

Penulis menyampaikan terima kasih kepada: (1) Rektor Universitas Muhammadiyah Mataram (UMMAT) atas fasilitas yang diberikan (2) Dekan FKIP UMMAT beserta jajarannya, atas saran dan fasilitas yang diberikan (3) Kepala sekolah SDN 5 Kuranji yang telah memberikan ijin dan fasilitas pada kegiatan penelitian ini sehingga dapat terlaksana dengan lancar.

\section{DAFTAR PUSTAKA}

Anggraeni, S. W., Alpian, Y., Prihamdani, D., \& Winarsih, E. (2021). Pengembangan Multimedia Pembelajaran Interaktif Berbasis Video Untuk Meningkatkan Minat Belajar Siswa Sekolah Dasar. Jurnal Basicedu, 5(3), 1683-1688. Https://Jbasic.Org/Index.Php/Basicedu/Article/View/1636/Pdf

Awang, I. S. (2015). Kesulitan Belajar Ipa Peserta Didik Sekolah Dasar. Vox Edukasi, 6(2), 143-155.

Desstya, A. (2015). Keterampilan Proses Sains Dan Pembelajaran Ipa Di Sekolah Dasar (Telaah Buku Siswa Kelas Iv Sd Tema 2 Karya Sumini). Profesi Pendidikan Dasar, 2(2), 95-102.

Emda, A. (2018). Kedudukan Motivasi Belajar Siswa Dalam Pembelajaran. Lantanida Journal, 5(2), 172. Https://Doi.Org/10.22373/Lj.V5i2.2838

Hakim, I. N. (1970). Pembelajaran Tematik-Integratif Di Sd/Mi Dalam Kurikulum 2013. Insania : Jurnal Pemikiran Alternatif Kependidikan, 19(1), 46-59. Https://Doi.Org/10.24090/Insania.V19i1.463

Hariani, T., Haifaturrahmah, Sari, N., \& Mariyati, Y. (2021). Pengembangan Media Kartu Bergambar Untuk Siswa Sekolah Dasar. Seminar Nasional Paedagoria, 101-107. Http://Journal.Ummat.Ac.Id/Index.Php/Fkip/Article/View/6035

Hidayah, N., Pgmi, J., Tarbiyah, F., \& Keguruan, D. (2015). Tematik Sd. Terampil Pendidikan Dan Pembelajaran Dasar, 2, 34-49.

Kamaladini, Gani, A. A., \& Sari, N. (2021). Pengembangan Media Papan Edukasi Pintar Dalam Meningkatkan Motivasi Belajar Siswa Sekolah Dasar. 1(September), 93-100.

Lahadisi. (2014). Inkuiri : Sebuah Strategi Menuju. Jurnal Al-Ta'dib, 7(2), 85-98.

Mujahadah, I., Alman, A., \& Triono, M. (2021). Pengembangan Media Pembelajaran Komik Untuk Meningkatkan Hasil Dan Minat Belajar Matematika Peserta Didik Kelas Iii Sd Muhammadiyah Malawili. Jurnal Papeda: Jurnal Publikasi Pendidikan Dasar, 3(1), 8-15. Https://Doi.Org/10.36232/Jurnalpendidikandasar.V3i1.758

Rumhadi, T. (2017). Urgensi Motivasi Dalam Proses Pembelajaran. Jurnal Diklat Keagamaan, 11(1), 33-41. Bdksurabaya.E-Journal.Id? Article ? Download

Sari, N., \& A.K. Prodjosantoso. (2016). Pengembangan Media Komik Ipa Model Inkuiri Terbimbing Untuk Meningkatkan Aspek Kognitif Peserta Didik Smp. Revitalisasi Budaya Lokal Dalam Menghadapi Tantangan Pendidikan Pada Era Masyarakat Ekonomi Asean (Mea), 72-78.

Sari, N., \& Prodjosantoso, A. K. (2018). Pengembangan Media Komik Ipa Model Inkuiri Terbimbing Untuk Meningkatkan Aspek Kognitif Peserta Didik Smp. Jurnal Elementary, 1(1), 5-10. Https://Doi.Org/10.31764/Elementary.V1i1.138

Sari, N., \& Rahman, N. (2018). Peningkatan Motivasi Dan Kemampuan Kognitif Ipa Melalui Penerapan Model Cooperative Learning Tipe Jigsaw. Pancasakti Science Education Journal Psej Volume 3 Nomor 
6195 Pengembangan Media Komik Bermuatan IPA Berbasis Model Inkuiri Terbimbing dalam Meningkatkan Motivasi Siswa Sekolah Dasar - Nursina Sari, Tursina Ratu

DOI: https://doi.org/10.31004/basicedu.v5i6.1793

1, April 2018, (Hal. 34- 42), 3(April), 34-42. Http://E-Journal.Ups.Ac.Id/Index.Php/Psej

Setiasih, S. Della, \& Panjaitan, R. L. (2016). Penggunaan Model Inkuiri Untuk Meningkatkan Hasil Belajar Siswa Pada Materi Sifat-Sifat Magnet Di Kelas V Sdn Sukajaya Kecamatan Jatinunggal Kabupaten Sumedang. Jurnal Pena Ilmiah, 1(1), 421-430. Https://Doi.Org/10.23819/Pi.V1i1.3051

Sidik, Z., \& Sobandi, A. (2018). Upaya Meningkatkan Motivasi Belajar Siswa Melalui Kemampuan Komunikasi Interpersonal Guru. Jurnal Pendidikan Manajemen Perkantoran, 3(2), 50. Https://Doi.Org/10.17509/Jpm.V3i2.11764

Silviana, A., Mulyana, E. H., \& Giyartini, R. (2018). Pedadidaktika : Jurnal Ilmiah Pendidikan Guru Sekolah Dasar Penggunaan Model Inkuiri Pendekatan Eksperimental Untuk Meningkatkan Penguasaan Siswa Terhadap Konsep Sifat-Sifat Cahaya. 5(1), 1-10.

Siska, J., \& Kristiawan. (2021). Pengembangan Modul Pembelajaran Terhadap Hasil Belajar Mata Pelajaran Aqidah Di Sekolah Dasar. Jurnal Basicedu, 5(6), 5035-5042. Http://Jbasic.Org/Index.Php/Basicedu/Article/View/1570

Wibowo, S. A., \& Koeswanti, H. D. (2021). Pengembangan Media Pembelajaran Berbasis Komik Untuk Meningkatkan Karakter Kemandirian Belajar Siswa Sekolah Dasar Susetyo Andri Wibowo $1 \square$, Henny Dewi Koeswanti 2. Jurnal Basicedu, 5(6), 5100-5111. Https://Jbasic.Org/Index.Php/Basicedu/Article/View/1600

Widyawati, A., \& Prodjosantoso, A. K. (2015). Pengembangan Media Komik Ipa Untuk Meningkatkan Motivasi Belajar Dan Karakter Peserta Didik Smp. Jurnal Inovasi Pendidikan Ipa, 1(1), 24. Https://Doi.Org/10.21831/Jipi.V1i1.4529

Zaenal Fais, M., Listyarini, I., \& Nashir Tsalatsa, A. (2019). Pengembangan Media Papin Dan Koja (Papan Pintar Dan Kotak Ajaib) Sebagai Media Pembelajaran Matematika. Jurnal Penelitian Dan Pengembangan Pendidikan, 3(1), 26. Https://Doi.Org/10.23887/Jppp.V3i1.17097 